\title{
Assessing the Performances of Protein Function Prediction Algorithms from the Perspectives of Identification Accuracy and False Discovery Rate
}

\author{
Chun Yan Yu ${ }^{1,2}$, Xiao Xu Li ${ }^{1,2}$, Hong Yang ${ }^{1,2}$, Ying Hong $\mathrm{Li}^{1,2}$, Wei Wei Xue ${ }^{1}$, Yu Zong Chen ${ }^{3}$, \\ Lin Tao ${ }^{4}$ and Feng Zhu ${ }^{1,2, *}$ \\ 1 Innovative Drug Research and Bioinformatics Group, School of Pharmaceutical Sciences and Collaborative \\ Innovation Center for Brain Science, Chongqing University, Chongqing 401331, China; \\ yucy@cqu.edu.cn (C.Y.Y.); lixiaoxu@cqu.edu.cn (X.X.L.); yangh0921@cqu.edu.cn (H.Y.); \\ liyh@cqu.edu.cn (Y.H.L.); xueww@cqu.edu.cn (W.W.X.) \\ 2 Innovative Drug Research and Bioinformatics Group, College of Pharmaceutical Sciences, \\ Zhejiang University, Hangzhou 310058, China \\ 3 Bioinformatics and Drug Design Group, Department of Pharmacy, and Center for Computational Science \\ and Engineering, National University of Singapore, Singapore 117543, Singapore; 20121802134@cqu.edu.cn \\ 4 School of Medicine, Hangzhou Normal University, Hangzhou 310012, China; linntaoo@hotmail.com \\ * Correspondence: zhufeng.ns@gmail.com or zhufeng@cqu.edu.cn
}

Received: 22 October 2017; Accepted: 4 January 2018; Published: 8 January 2018

\begin{abstract}
The function of a protein is of great interest in the cutting-edge research of biological mechanisms, disease development and drug/target discovery. Besides experimental explorations, a variety of computational methods have been designed to predict protein function. Among these in silico methods, the prediction of BLAST is based on protein sequence similarity, while that of machine learning is also based on the sequence, but without the consideration of their similarity. This unique characteristic of machine learning makes it a good complement to BLAST and many other approaches in predicting the function of remotely relevant proteins and the homologous proteins of distinct function. However, the identification accuracies of these in silico methods and their false discovery rate have not yet been assessed so far, which greatly limits the usage of these algorithms. Herein, a comprehensive comparison of the performances among four popular prediction algorithms (BLAST, SVM, PNN and KNN) was conducted. In particular, the performance of these methods was systematically assessed by four standard statistical indexes based on the independent test datasets of 93 functional protein families defined by UniProtKB keywords. Moreover, the false discovery rates of these algorithms were evaluated by scanning the genomes of four representative model organisms (Homo sapiens, Arabidopsis thaliana, Saccharomyces cerevisiae and Mycobacterium tuberculosis). As a result, the substantially higher sensitivity of SVM and BLAST was observed compared with that of PNN and KNN. However, the machine learning algorithms (PNN, KNN and SVM) were found capable of substantially reducing the false discovery rate (SVM $<\mathrm{PNN}<\mathrm{KNN}$ ). In sum, this study comprehensively assessed the performance of four popular algorithms applied to protein function prediction, which could facilitate the selection of the most appropriate method in the related biomedical research.
\end{abstract}

Keywords: false discovery rate; machine learning; protein function prediction; support vector machine; BLAST

\section{Introduction}

The function of a protein is of great interest in the current research of biological mechanisms [1], disease development [2] and drug/target discovery [3-7], and a variety of databases is available 
for providing functional annotations from the perspectives of the sequence [8], protein-protein interaction [9,10], the biological network [11-15] and many specific functional classes [16-22]. However, a substantial gap is still observed between the total number of protein sequences discovered and that of proteins characterized with known function [23]. To cope with this gap, thousands of high-throughput genome projects are under study [24], and over 13 million sequences have been discovered, but only $1 \%$ of these validated by experimental annotation [25]. Apart from those experimental approaches, many in silico methods have been designed and extensively used to discover protein functions [26]. These include clustering of sequences [27], gene fusion [28], sequence similarity [29,30], evolution study [31], structural comparison [32], protein-protein interaction [33,34], functional classification via the sequence-derived [35-38] and domain [39-43] feature, omics profiling [44-47] and integrated methods, which collectively consider multiple methods and data to promote the performance of function prediction [48-51].

Among these in silico methods [52], the basic local alignment search tool (BLAST) [53] revealing protein functions based on excess sequence similarity [54] demonstrated great capacity and attracted substantial interest from the researchers of this field [55,56]. Apart from BLAST, machine learning algorithms have been frequently applied in recent years for functional prediction [57-62], and a variety of online software tools based on machine learning was developed as predictors without considering the similarity in sequence or structure [36,63]. This unique characteristic makes machine learning a good complement to other in silico approaches in predicting the function of remotely relevant protein and the homologous proteins of distinct functions [64,65].

So far, three machine learning algorithms, including K-nearest neighbor (KNN), probabilistic neural network (PNN) and support vector machine (SVM), have been extensively explored to classify proteins into certain functional families by analyzing the sequence-based physicochemical property $[64,65]$ and to assess protein functional classes collectively [63]. These algorithms are recognized as powerful alternative methods for predicting the function of both proteins [66-70] and other molecules [71]. However, over one third of the protein sequences in UniProt [26] are still labeled as "putative", "uncharacterized", "unknown function" or "hypothetical", and the difficulty in discovering the function of the remaining proteins is reported to come mainly from the false discovery rate of in silico algorithms $[55,56,72]$. Moreover, the identification accuracies of those approaches still need to be further improved $[55,56,73]$. Thus, it is urgently needed to assess the identification accuracies and false discovery rates among those different in silico approaches.

In this study, the performances of four popular functional prediction algorithms (BLAST, SVM, KNN and PNN) were comprehensively evaluated from two perspectives. In particular, the identification accuracies (measured by four standard statistical indexes) of various algorithms were systematically evaluated based on the independent test data of 93 functional families. Secondly, the false discovery rates of these algorithms were compared by scanning the genomes of four representative model species (Homo sapiens, Arabidopsis thaliana, Saccharomyces cerevisiae and Mycobacterium tuberculosis). In sum, these findings provided detailed information on the performances of those algorithms that are popular for protein function prediction, which may facilitate the choice of the appropriate algorithm(s) in the related biomedical research.

\section{Results and Discussion}

\subsection{Assessment of the Identification Accuracies Measured by Four Popular Metrics}

The statistical differences in sensitivity (SE) (Figure 1A), specificity (SP) (Figure 1B), accuracy $(A C C)$ (Figure 1C) and Matthews correlation coefficient (MCC) (Figure 1D) among four popular functional prediction algorithms are illustrated. As illustrated in Figure 1A, the SE of BLAST measured by the independent test dataset of 93 families was roughly equivalent to that of SVM, but statistically higher than that of both PNN and KNN. In particular, the $S E$ of 93 functional families was 50.00 99.99\% for SVM, 43.93 99.99\% for BLAST, 65.52 99.99\% for PNN and 51.09 99.99\% for KNN, and the 
SE median values of BLAST, SVM, PNN and KNN equaled $90.59 \%, 90.52 \%, 84.38 \%$ and $76.54 \%$, respectively. As shown in Figure 1B, the majority of the SPS of all algorithms surpassed $98.00 \%$; SPS of 93 functional families were 95.90 99.99\% for SVM, 97.56 99.99\% for BLAST, 98.87 99.99\% for PNN and $97.77 \sim 99.43 \%$ for KNN; and the SP median value of BLAST, SVM, PNN and KNN was $98.90 \%$, $99.72 \%, 99.67 \%$ and $99.44 \%$, respectively. These results revealed a relatively low level of false discovery rates for all popular functional prediction algorithms.
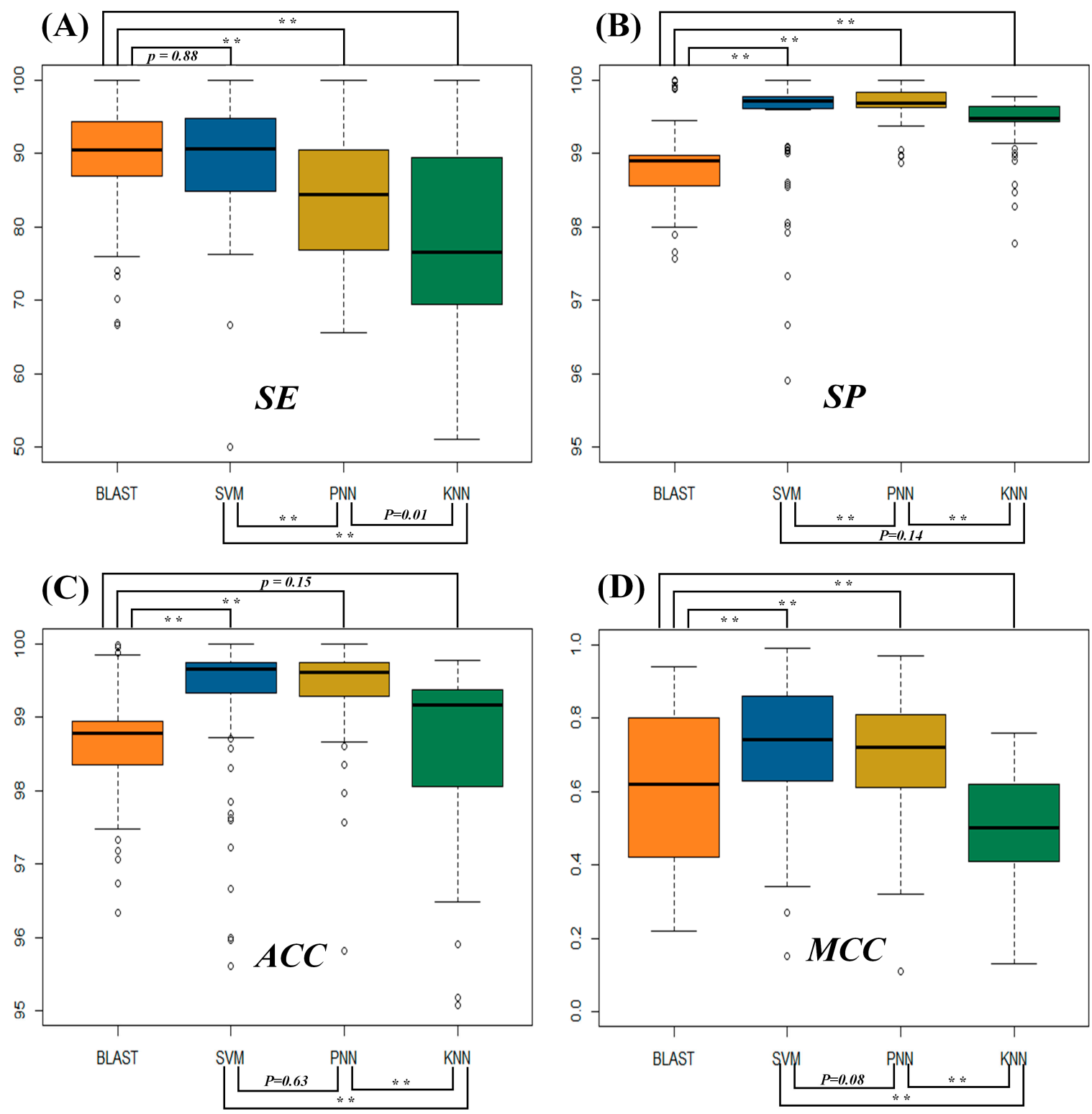

Figure 1. Statistical differences in the performance of four protein function prediction algorithms (BLAST, SVM, PNN and KNN) assessed by four metrics: (A) sensitivity (SE); (B) specificity (SP); (C) accuracy $(A C C)$; and (D) Matthews correlation coefficient $(M C C)$. Significant and moderately significant differences were shown by a $p$-value of $\left.<0.01{ }^{* *}\right)$, respectively.

Due to the dominant number of negative samples in the independent test datasets, the statistical difference in ACC was very similar to that of SP (Figure 1C). The majority of the ACCs of all algorithms surpassed $97 \%$. The ACCs of 93 functional families were between $95.61 \%$ and $99.99 \%$ for SVM, between $66.68 \%$ and $99.98 \%$ for BLAST, between $95.81 \%$ and $99.99 \%$ for PNN and between $81.39 \%$ and $99.77 \%$ for KNN. Moreover, median values of ACCs of BLAST, SVM, PNN and KNN equaled 98.78\%, 99.66\%, 
$99.61 \%$ and $99.16 \%$, respectively. MCC was frequently applied to reflect the stability of the protein function predictor and was considered as one of the most comprehensive parameters because of its full consideration of TP, TN, FP and FN. As shown in Figure 1D, the MCC of both SVM and PNN was better than that of BLAST and KNN. The majority of MCCs were over 0.6 and 0.4 for SVM-PNN and BLAST-KNN, respectively. In particular, MCCs of 93 functional families were between 0.15 and 0.99 for SVM, between 0.22 and 0.94 for BLAST, between 0.11 and 0.97 for PNN and between 0.13 and 0.76 for KNN. The median values of MCCs for BLAST, SVM, PNN and KNN equaled 0.62, 0.74, 0.72 and 0.50 , respectively. In sum, there were consistently low levels of the false discovery rate among all algorithms as assessed by the metric $S P$. However, when the positive discovery rates (SEs) and the stability of prediction (MCC) were considered, SVM, PNN and BLAST stood out as more powerful algorithms for protein function prediction.

\subsection{Evaluating the Statistical Differences in SE and MCC among Four Metrics}

For the machine learning algorithms (SVM, PNN and KNN), there was a significant statistical difference in their SEs and MCCS. As shown in Figure 1A, the statistical difference in SEs between SVM and PNN equaled $3.5 \times 10^{-6}$, while that between SVM and KNN was $1.0 \times 10^{-11}$. Moreover, there was a significant statistical difference between PNN and KNN ( $p$-value $=0.01)$. In particular, the number of families with SEs of $>90 \%, \leq 90 \%$ and $>80 \%$ and $\leq 80 \%$ for SVM equaled 49,33 and 11 , respectively; the number of families with $S E S$ of $>90 \%, \leq 90 \%$ and $>80 \%$ and $\leq 80 \%$ for PNN equaled 17,25 and 20, respectively; and the number of functional families with $S E S$ of $>90 \%, \leq 90 \%$ and $>80 \%$ and $\leq 80 \%$ for KNN equaled 19,13 and 45 , respectively. Similar to the $S E$, the statistical difference in MCC between SVM and PNN was 0.08 , and that between SVM and KNN was $2.2 \times 10^{-16}$. Moreover, there was a clear statistical difference between PNN and KNN ( $p$-value $\left.=2.2 \times 10^{-16}\right)$. In particular, the number of families with MCCs of $>0.85, \leq 0.85$ and $>0.7$ and $\leq 0.7$ for SVM was 26,26 and 41, respectively; the number of functional families with MCCs of $>0.85, \leq 0.85$ and $>0.7$ and $\leq 0.7$ for PNN equaled 6, 29 and 27, respectively; and there were no protein families with MCCs over 0.7 for KNN. In summary, there were clear ascending trends in both $S E$ and $M C C$ as shown in Figure $1 \mathrm{~A}, \mathrm{D}$ (from KNN to PNN to SVM).

Similar to SVM, BLAST also demonstrated great performances in both SE and MCC. The statistical differences (measured by $p$-value) in the SE and MCC between BLAST and SVM were 0.88 and $2.0 \times 10^{-7}$, respectively. As demonstrated in Table 1 and Table S1, the SE of BLAST surpassed that of SVM in 51 families, but was worse than that of SVM in 40 families. Moreover, the SEs' median values ( $90.52 \%$ for BLAST and $90.59 \%$ for SVM) and mean values ( $88.92 \%$ for BLAST and $89.08 \%$ for SVM) indicated that the $S E$ of SVM was slightly better than that of BLAST and significantly better than that of PNN and KNN. Meanwhile, MCC of SVM was higher than that of BLAST in 68 families, but was lower than that of BLAST in 20 families. The MCCs' median values ( 0.62 for BLAST, 0.74 for SVM) and mean values ( 0.61 for BLAST, 0.73 for SVM) indicated a slight improvement in prediction stabilities by SVM.

The amphibian defense peptide family (KW-0878; KW, keyword) was the family with the highest SE $(99.99 \%)$ for SVM, BLAST and KNN, which was known to be a rich source of antimicrobial peptides with a broad spectrum of antimicrobial activities against pathogenic microorganisms [74-76]. The superior $S E$ of this family may come from its nature as a conserved element of the defense system of various species [77]. 
Table 1. The performance of four protein function prediction algorithms assessed by four popular metrics: sensitivity (SE), specificity (SP), accuracy ( $A C C)$ and Matthews correlation coefficient (MCC).

\begin{tabular}{|c|c|c|c|c|c|c|c|c|c|c|c|c|c|c|c|c|c|c|}
\hline \multirow{2}{*}{$\begin{array}{l}\text { UniProt } \\
\text { Keyword }\end{array}$} & \multirow{2}{*}{$\begin{array}{l}\text { Protein Functional } \\
\text { Family }\end{array}$} & \multirow{2}{*}{$\begin{array}{c}\text { GO } \\
\text { Category }\end{array}$} & \multicolumn{4}{|c|}{ BLAST } & \multicolumn{4}{|c|}{ SVM } & \multicolumn{4}{|c|}{ PNN } & \multicolumn{4}{|c|}{ KNN } \\
\hline & & & $S E \%$ & $S P \%$ & $A C \%$ & $M C C$ & $S E \%$ & $S P \%$ & $A C \%$ & $M C C$ & $S E \%$ & $S P \%$ & $A C \%$ & $M C C$ & $S E \%$ & $S P \%$ & $A C \%$ & $M C C$ \\
\hline KW-0020 & Allergen & - & 76.32 & 98.92 & 98.78 & 0.48 & 84.81 & 99.69 & 99.66 & 0.57 & 86.42 & 99.84 & 99.81 & 0.69 & 74.07 & 99.48 & 99.32 & 0.41 \\
\hline KW-0049 & Antioxidant & GO:0016209 & 94.15 & 99.23 & 99.20 & 0.60 & 89.00 & 99.76 & 99.73 & 0.67 & 86.00 & 99.84 & 99.80 & 0.71 & 69.00 & 99.42 & 99.24 & 0.43 \\
\hline KW-0117 & Actin capping & GO:0051693 & 94.55 & 99.08 & 99.07 & 0.35 & 93.98 & 99.75 & 99.74 & 0.70 & 91.18 & 99.80 & 99.78 & 0.71 & 73.53 & 99.42 & 99.22 & 0.43 \\
\hline KW-0147 & Chitin-binding & GO:0008061 & 86.96 & 98.96 & 98.94 & 0.34 & 91.75 & 99.72 & 99.68 & 0.78 & 75.36 & 99.61 & 99.47 & 0.63 & 93.84 & 98.57 & 98.05 & 0.37 \\
\hline KW-0157 & Chromophore & GO:0018298 & 96.70 & 98.54 & 98.51 & 0.70 & 93.83 & 99.74 & 99.68 & 0.86 & 86.91 & 99.66 & 99.52 & 0.80 & 89.38 & 99.48 & 98.53 & 0.59 \\
\hline KW-0195 & Cyclin & GO:0061575 & 89.34 & 98.92 & 98.89 & 0.44 & 97.96 & 99.78 & 99.78 & 0.60 & 89.80 & 99.84 & 99.83 & 0.62 & 75.51 & 99.63 & 99.53 & 0.39 \\
\hline KW-0251 & Elongation factor & GO:0003746 & 99.51 & 98.57 & 98.60 & 0.83 & 96.72 & 99.67 & 99.62 & 0.92 & 84.14 & 99.67 & 99.29 & 0.85 & 95.84 & 99.46 & 97.21 & 0.63 \\
\hline KW-0339 & Growth factor & GO:0008083 & 94.05 & 98.99 & 98.95 & 0.65 & 84.30 & 99.69 & 99.62 & 0.76 & 86.01 & 99.81 & 99.72 & 0.80 & 76.54 & 99.66 & 99.16 & 0.61 \\
\hline KW-0343 & GTPase activation & GO:0005096 & 76.06 & 98.57 & 98.40 & 0.47 & 92.45 & 99.67 & 99.65 & 0.66 & 86.73 & 99.82 & 99.78 & 0.72 & 61.95 & 99.44 & 99.25 & 0.46 \\
\hline KW-0344 & $\begin{array}{l}\text { Guanine-nucleotide } \\
\text { releasing factor }\end{array}$ & GO:0005085 & 74.09 & 98.57 & 98.44 & 0.39 & 83.33 & 99.72 & 99.69 & 0.57 & 89.74 & 99.64 & 99.62 & 0.56 & 93.59 & 99.15 & 98.95 & 0.31 \\
\hline KW-0396 & Initiation factor & GO:0003743 & 96.88 & 98.92 & 98.86 & 0.83 & 91.36 & 99.66 & 99.50 & 0.87 & 74.21 & 99.82 & 99.32 & 0.81 & 77.64 & 99.45 & 97.98 & 0.65 \\
\hline KW-0497 & Mitogen & GO:0051781 & 89.25 & 98.98 & 98.96 & 0.40 & 92.74 & 99.73 & 99.66 & 0.85 & 83.60 & 99.61 & 99.45 & 0.75 & 85.22 & 99.62 & 98.78 & 0.62 \\
\hline KW-0505 & Motor protein & GO:0098840 & 93.38 & 98.96 & 98.91 & 0.63 & 89.47 & 99.75 & 99.72 & 0.69 & 80.70 & 99.86 & 99.80 & 0.72 & 64.04 & 99.45 & 99.25 & 0.46 \\
\hline KW-0514 & Muscle protein & - & 94.22 & 98.95 & 98.92 & 0.57 & 95.38 & 99.75 & 99.73 & 0.74 & 89.23 & 99.69 & 99.65 & 0.67 & 80.00 & 99.60 & 99.32 & 0.51 \\
\hline KW-0515 & Mutator protein & GO:1990633 & 97.65 & 98.97 & 98.97 & 0.42 & 83.82 & 99.79 & 99.76 & 0.60 & 77.94 & 99.84 & 99.80 & 0.61 & 70.59 & 99.45 & 99.32 & 0.38 \\
\hline KW-0568 & $\begin{array}{l}\text { Pathogenesis related } \\
\text { protein }\end{array}$ & GO:0009607 & 92.86 & 98.98 & 98.97 & 0.29 & 93.36 & 99.78 & 99.74 & 0.89 & 94.87 & 99.63 & 99.58 & 0.84 & 91.20 & 99.71 & 98.72 & 0.64 \\
\hline KW-0734 & $\begin{array}{l}\text { Signal transduction } \\
\text { inhibitor }\end{array}$ & GO:0009968 & 81.25 & 98.97 & 98.94 & 0.31 & 84.62 & 99.71 & 99.69 & 0.45 & 84.62 & 99.68 & 99.66 & 0.43 & 87.18 & 99.63 & 99.54 & 0.34 \\
\hline KW-0786 & $\begin{array}{c}\text { Thiamine } \\
\text { pyrophosphate binding }\end{array}$ & - & 97.08 & 98.95 & 98.93 & 0.71 & 96.04 & 99.73 & 99.70 & 0.85 & 87.70 & 99.89 & 99.79 & 0.87 & 74.76 & 99.43 & 98.80 & 0.58 \\
\hline KW-0830 & Ubiquinone binding & - & 98.37 & 98.50 & 98.49 & 0.87 & 94.07 & 99.72 & 99.56 & 0.92 & 82.58 & 99.46 & 98.98 & 0.82 & 91.47 & 99.73 & 97.20 & 0.68 \\
\hline KW-0847 & Vitamin $C$ binding & GO:0031418 & 94.21 & 98.96 & 98.94 & 0.46 & 91.89 & 99.79 & 99.78 & 0.53 & 97.30 & 99.69 & 99.69 & 0.48 & 81.08 & 99.64 & 99.56 & 0.35 \\
\hline
\end{tabular}




\subsection{In-Depth Assessment of the False Discovery Rate by Genome Scanning}

Genome scanning has been frequently used to evaluate the false discovery rate of function prediction tools $[78,79]$. To have a comprehensive understanding of methods' false discovery rate, the genomes of four model organisms representing four kingdoms (Homo sapiens from Animalia, Arabidopsis thaliana from Plantae, saccharomyces cerevisiae from Fungi and Mycobacterium tuberculosis from Bacteria) were collected. As demonstrated in Table 2 and Table S2, the genome scanning revealed that the number of proteins in any of those 93 studied families predicted by SVM, PNN and KNN did not exceed $10 \%$ of the total number of proteins in the whole genome, and this was the same situation for the majority ( $82 \%$ ) of the 93 studied families by BLAST. The higher number of proteins predicted for a certain functional family may indicate a higher false discovery rate $[78,79]$. For the human genome, the number of proteins identified by SVM was equivalent to or was slightly higher than that of both PNN and KNN, but was significantly lower than that of BLAST (Figure 2a). In addition, the proteins identified by PNN were lower than that of KNN in 11 families and higher in 20 families.
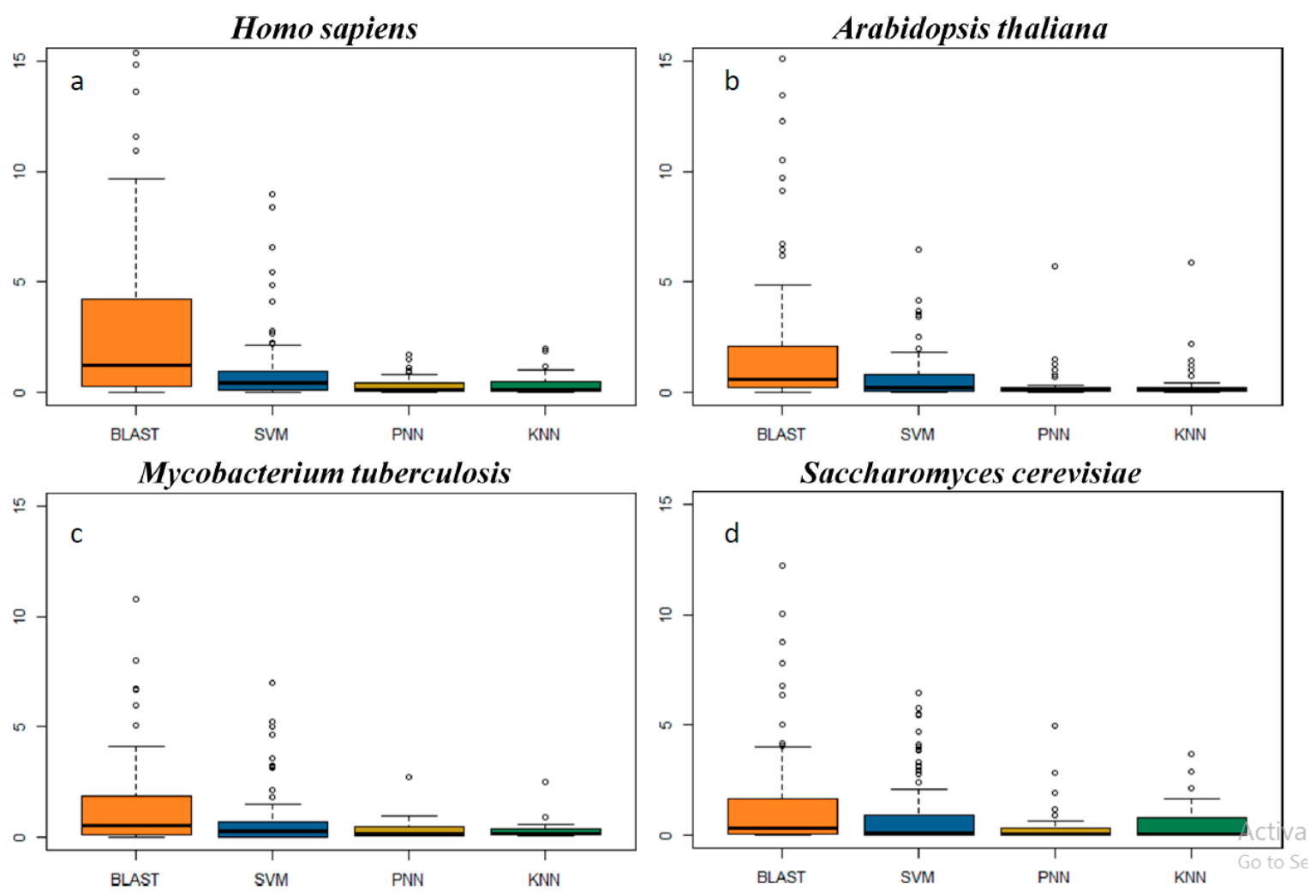

Figure 2. The false discovery rates reflected by the percentage of proteins identified from the genomes of (a) Homo sapiens, (b) Arabidopsis thaliana, (c) Saccharomyces cerevisiae and (d) Mycobacterium tuberculosis. 
Table 2. The false discovery rate assessed by the percentage of proteins identified from human and thaliana genomes by different algorithms.

\begin{tabular}{|c|c|c|c|c|c|c|c|c|c|c|c|}
\hline \multirow{2}{*}{$\begin{array}{l}\text { UniProt } \\
\text { Keyword }\end{array}$} & \multirow{2}{*}{ Protein Functional Family } & \multicolumn{5}{|c|}{ Homo Sapiens } & \multicolumn{5}{|c|}{ Arabidopsis Thaliana } \\
\hline & & UniProt (\%) & SVM (\%) & BLAST (\%) & PNN (\%) & KNN (\%) & UniProt (\%) & SVM (\%) & BLAST (\%) & PNN (\%) & KNN (\%) \\
\hline KW-0117 & Actin capping & 0.09 & 0.12 & 0.72 & 0.10 & 0.10 & 0.05 & 0.07 & 0.11 & 0.05 & 0.05 \\
\hline KW-0020 & Allergen & 0.02 & 0.18 & 3.68 & 0.11 & 0.04 & 0.01 & 0.17 & 6.22 & 0.07 & 0.09 \\
\hline KW-0049 & Antioxidant & 0.07 & 0.09 & 0.50 & 0.08 & 0.07 & 0.09 & 0.16 & 1.11 & 0.12 & 0.13 \\
\hline KW-0147 & Chitin-binding & 0.02 & 0.16 & 0.36 & 0.02 & 0.10 & 0.08 & 0.24 & 3.57 & 0.08 & 0.18 \\
\hline KW-0157 & Chromophore & 0.07 & 0.15 & 2.10 & 0.07 & 0.10 & 0.28 & 0.38 & 0.88 & 0.23 & 0.30 \\
\hline KW-0195 & Cyclin & 0.16 & 0.24 & 0.40 & 0.18 & 0.19 & 0.33 & 0.36 & 0.61 & 0.34 & 0.34 \\
\hline KW-0251 & Elongation factor & 0.08 & 0.11 & 0.45 & 0.08 & 0.09 & 0.15 & 0.19 & 0.48 & 0.14 & 0.16 \\
\hline KW-0339 & Growth factor & 0.65 & 0.93 & 2.50 & 0.71 & 0.73 & 0.12 & 0.18 & 0.24 & 0.13 & 0.14 \\
\hline KW-0343 & GTPase activation & 0.97 & 1.19 & 5.47 & 0.93 & 1.02 & 0.28 & 0.24 & 1.36 & 0.21 & 0.23 \\
\hline KW-0344 & Guanine-nucleotide releasing factor & 0.73 & 0.86 & 5.37 & 0.73 & 0.75 & 0.18 & 0.20 & 2.12 & 0.17 & 0.19 \\
\hline KW-0396 & Initiation factor & 0.24 & 0.39 & 1.70 & 0.26 & 0.25 & 0.26 & 0.38 & 1.71 & 0.24 & 0.28 \\
\hline KW-0497 & Mitogen & 0.20 & 0.65 & 4.37 & 0.30 & 0.35 & 0.00 & 0.07 & 0.52 & 0.01 & 0.02 \\
\hline KW-0505 & Motor protein & 0.66 & 0.75 & 4.07 & 0.67 & 0.67 & 0.59 & 0.45 & 2.14 & 0.34 & 0.42 \\
\hline KW-0514 & Muscle protein & 0.31 & 0.42 & 4.35 & 0.37 & 0.39 & 0.00 & 0.17 & 1.26 & 0.11 & 0.13 \\
\hline KW-0515 & Mutator protein & 0.01 & 0.02 & 0.05 & 0.01 & 0.01 & 0.01 & 0.01 & 0.05 & 0.01 & 0.01 \\
\hline KW-0568 & Pathogenesis-related protein & 0.00 & 0.08 & 0.09 & 0.04 & 0.05 & 0.13 & 0.20 & 0.91 & 0.15 & 0.16 \\
\hline KW-0734 & Signal transduction inhibitor & 0.22 & 0.23 & 1.22 & 0.21 & 0.21 & 0.01 & 0.01 & 0.74 & 0.01 & 0.01 \\
\hline KW-0786 & Thiamine pyrophosphate binding & 0.06 & 0.07 & 0.13 & 0.06 & 0.06 & 0.12 & 0.15 & 0.28 & 0.13 & 0.14 \\
\hline KW-0830 & Ubiquinone binding & 0.08 & 0.71 & 0.12 & 0.19 & 0.60 & 0.13 & 0.25 & 0.42 & 0.17 & 0.18 \\
\hline KW-0847 & Vitamin $C$ binding & 0.10 & 0.12 & 0.18 & 0.10 & 0.09 & 0.07 & 0.11 & 0.53 & 0.07 & 0.08 \\
\hline
\end{tabular}


Moreover, 15 protein families only existing in plants, microbes or viruses (Table S3, not existing in the human genome) were collected for assessing the false discovery rate of each algorithm. For example, the covalent protein-RNA linkage family (KW-0191) contained proteins attaching covalently to the RNA molecules in virus [80], and the storage protein (KW-0758) included the proteins as a source of nutrients for the development or growth of the organism in plants. For these families (Table S3), SVM did not identify any proteins from the human genome, while $0.06 \%$ and $0.25 \%$ of the proteins in the human genome were falsely assigned by BLAST to the family of covalent protein-RNA linkage protein and storage protein, respectively. As illustrated in Figure 3, several other families (such as plant defense, virulence) also demonstrated a significantly higher false discovery rate by BLAST than that of SVM.

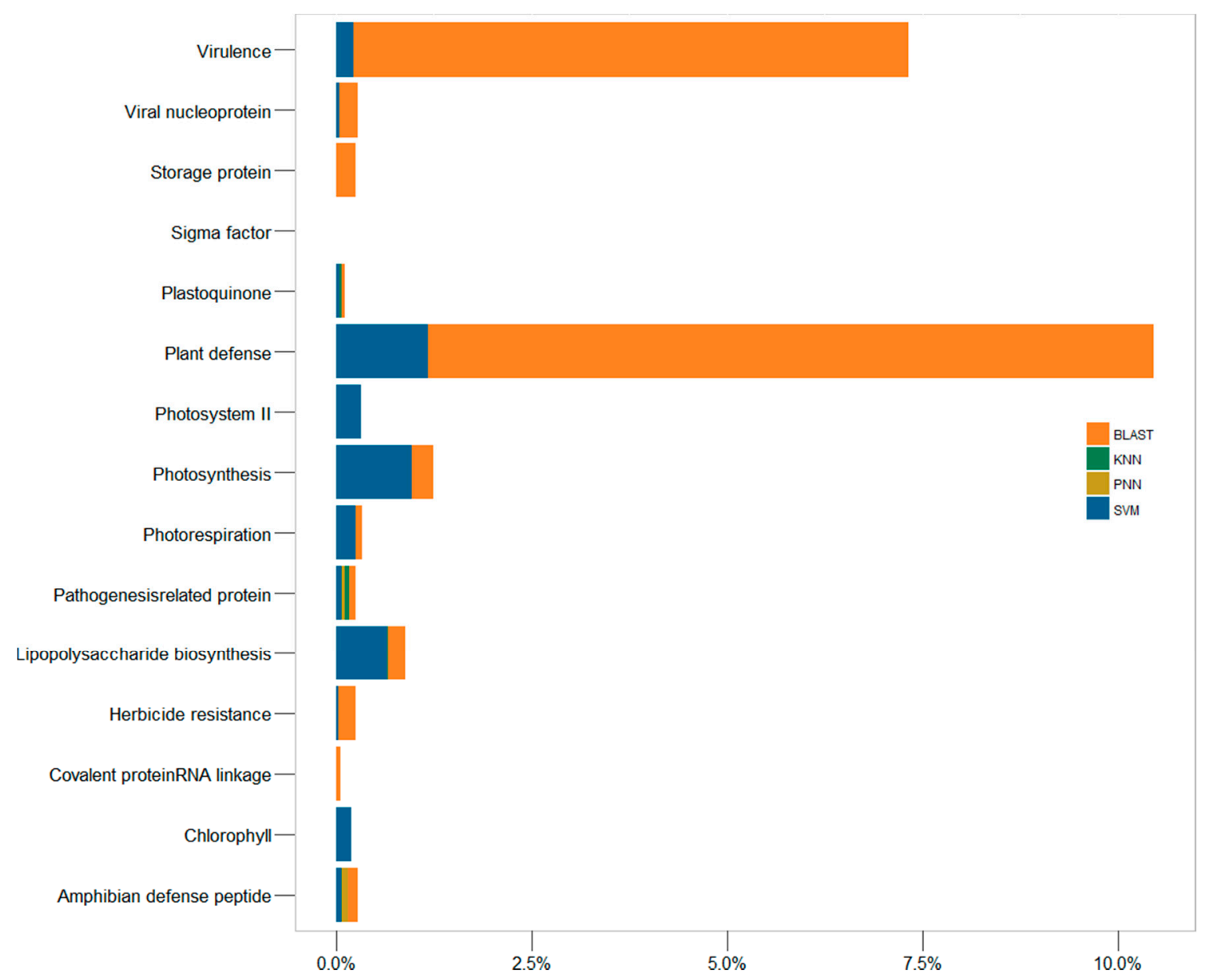

Figure 3. The false discovery rates reflected by the percentage of proteins of 15 protein families only existing in plants, microbes or viruses, but not existing in the human genome identified from the genomes of Homo sapiens.

For the other three genomes, their situation was similar to the human genome. Take the Arabidopsis thaliana genome as an example: proteins identified by SVM were equivalent to or slightly higher than those by PNN and KNN in all protein families, but lower than that of BLAST in 77 families, and the number of protein discovered by PNN was lower than that of KNN in 26 families. In summary, the level of false discovery rate (Figure $2 \mathrm{~b}-\mathrm{d}$ ) could be ordered as BLAST $>\mathrm{SVM}>\mathrm{PNN}$ and KNN. These results revealed that BLAST was more prone to generate a false discovery rate than the other three machine learning methods ( $\mathrm{SVM}>\mathrm{PNN} \approx \mathrm{KNN}$ ).

As reported [81-85], an open web-server is recognized as useful for constructing effective methods and tools. A variety of web-servers have increasing impacts on medical sciences [86], driving medicinal 
chemistry to an unprecedented revolution [87], and efforts will be further made to develop web-based services for the performance assessment discussed in this study.

\section{Materials and Methods}

To construct a valid statistical model for a biology problem based on protein sequences [88-97], a rule of five steps is needed [98]. Firstly, a valid construction of datasets for both training and testing the model is required. Secondly, an effective conversion of the sequence to the digital feature vector is asked to represent their targeted properties. Thirdly, a powerful statistical method should be designed for the functional prediction. Fourthly, the accuracies of the constructed statistic model should be validated correctly. Fifthly, a web-server based on the constructed model may be further developed for public access. The corresponding methods and steps adopted in this study are provided and described below.

\subsection{Collecting the Protein Sequences of Different Functional Families}

Table 1 provides a full list of 93 protein families collected from UniProt [43], and the performances of the popular protein function prediction methods (BLAST, KNN, PNN, SVM) were measured via independent test datasets (the way to generate an independent dataset is shown in the following Section 2.2). These 93 included 12 families of binding molecules (e.g., sodium-, potassium-, SH3- and RNA-binding), 15 ligand families (e.g., plastoquinone ligand, vitamin C ligand and ubiquinone ligand), 58 families defined by Gene Ontology ( 40 molecular functions and 18 biological processes) and 8 broad families defined by UniProt [43]. All families were contained in the keyword categories of UniProt, and the majority $(82.7 \%$ ) of these 93 families were able to be mapped to GO terms (Table 1 ). Protein entries that have not been manually annotated and reviewed by UniProtKB curators in a keyword category were not considered for analysis in this study. As a result, 107 49,517 protein-entries from 93 families were collected.

\subsection{Construction of the Training and Testing Datasets}

The independent test dataset was frequently constructed to evaluate the performances of protein function predictors in recent years [99-104]. To construct a valid set of data for building the predictor of each family, the datasets of the training, testing and independent test were generated by a strictly defined process after the data collection described in Section 2.1. Firstly, all proteins of different sequences in a specific family are assigned randomly with a number, which is within the range of the total number of proteins in that family. Secondly, these sequences in each protein function family were sequentially selected based on the number assigned and then iteratively added to the training, testing and independent test datasets. Samples in these datasets are all known as the positive samples. Thirdly, the Pfam families [16] of the proteins of a certain functional family were retrieved from the Pfam database [16] for generating negative samples. The Pfam family with protein(s) of this functional family was defined as the "positive" one, and the remaining families were grouped into the "negative" ones. Finally, 3 representatives were randomly picked out of the negative families and sequentially added to the training, testing and independent test datasets, and samples in these datasets are thus known as the negative samples. It is necessary to emphasize that there was no overlap among the datasets of the training, testing and independent test [60,61].

To assess the false discovery rate among algorithms, the genomes of four model organisms representing four kingdoms (Homo sapiens from Animalia, Arabidopsis thaliana from Plantae, Saccharomyces cerevisiae from Fungi and Mycobacterium tuberculosis from Bacteria) were collected from UniProt. The protein entries without any manual annotation and review by the UniProtKB curators were not taken into consideration. In total, 20,183, 15,169, 6721 and 2166 protein sequences in FASTA format were collected for human, Arabidopsis thaliana, Saccharomyces cerevisiae and Mycobacterium tuberculosis, respectively. 


\subsection{Feature Vectors Used for Representing the Protein Sequence}

The conversion of the protein sequence into the digital feature vector was conducted based on properties of each residue within that protein. These properties include: (1) charge; (2) polarizability; (3) polarity; (4) surface tension; (5) amino acid (AA) composition; (6) van der Waals volume via normalizing; (7) hydrophobicity; (8) solvent accessibility; and (9) protein secondary structure [36,105-107]. Then, 3 features were applied to describe each property [36]. These features contained: (a) composition (No. of AAs of a particular property over the total No. of AAs; (b) transition (the percentage of AAs with a certain property was followed by AAs with a different property); and (c) distribution (the sequence lengths within which the first, one fourth, half, three-quarters and all of the AAs of specific property were localized). The detailed procedure for generating the feature vector from the sequence was described in previous publications $[36,65]$. These features have already been successfully applied to facilitate the prediction of enzyme functional [108] and structural classes [107].

\subsection{Functional Prediction of Protein Constructed by Machine Learning}

To construct the prediction model, the parameters of machine learning methods were optimized using the testing dataset for each training process. Once suitable parameters were discovered, a new training set was constructed by combining the original training and testing datasets, and the corresponding parameters were directly accepted for training a new model. To assess the performance of the constructed models and detect possible over-fitting, the independent test set was further applied. It is necessary to emphasize that all duplicates in the protein sequence were removed during datasets' construction.

\subsection{Construction of Protein Functional Prediction Model Based on Sequence Similarity}

Sequence similarity was assessed by the NCBI Protein-Protein BLAST (Version 2.6.0+) [53,54]. Firstly, the combined training and testing dataset was adopted to form the BLAST database, and the sequences in the independent test dataset were used as queries. The BLAST E-value and percentage sequence identity were usually applied to represent the level of similarity between sequences [109]. The functional variation between proteins was reported to be rare when their sequence identity was more than $40 \%$ [110,111]. Thus, an E-value of 0.001 and a sequence identity of $40 \%$ were adopted as the cutoffs in this study to assess the functional conservation of BLAST hits.

\subsection{Assessing the Identification Accuracies of the Studied Methods}

The performance of protein function prediction algorithms was systematically assessed by four popular metrics, sensitivity (SE), specificity $(S P)$, accuracy $(A C C)$ and Matthews correlation coefficient $(M C C)$, based on the independent test datasets generated from the 93 studied families (Supplementary Materials Table S1). All 4 metrics were widely used in assessing the performance of protein function predictors [112-117]. In particular, SE is defined by the percentage of true positive samples correctly identified as "positive" [118,119] (shown in Equation (1)):

$$
S E=\frac{\mathrm{TP}}{\mathrm{TP}+\mathrm{FN}}
$$

$S P$ indicates the proportion of true negative samples that were correctly predicted as "negative" [118,119] (in Equation (2)):

$$
S P=\frac{\mathrm{TN}}{\mathrm{TN}+\mathrm{FP}}
$$

$A C C$ refers to the number of true samples (positive plus negative) divided by the number of all samples studied (shown in Equation (3)):

$$
A C C=\frac{\mathrm{TP}+\mathrm{TN}}{\mathrm{TP}+\mathrm{FN}+\mathrm{TN}+\mathrm{FP}}
$$


The $M C C$ was an important metric reflecting the stability of a protein function predictor, which described the correlation between a predictive value and an actual value $[118,119]$. It has been considered as one of the most comprehensive parameters in any category of predictors due to its full consideration of all four results. In particular, the MCC could be calculated by Equation 4:

$$
M C C=\frac{(\mathrm{TP} * \mathrm{TN}-\mathrm{FP} * \mathrm{FN})}{\sqrt{(\mathrm{TP}+\mathrm{FN}) *(\mathrm{TP}+\mathrm{FP}) *(\mathrm{TN}+\mathrm{FP}) *(\mathrm{TN}+\mathrm{FN})}}
$$

In particular, those four results were TP (No. of true positive samples), TN (No. of true negative samples), FP (No. of false positive samples) and FN (No. of false negative samples) $[118,119]$. It is very important to emphasize that these four metrics are applicable to the single-class situations (each protein is grouped into just one family). For the multi-class situations frequently observed in complicated biological networks [81-84] and biomedical researches [84,89,117], different metrics should be defined [120].

\subsection{The Rates of False Discovery of the In Silico Methods Studied Here}

As reported, genome scanning was a comprehensive method to evaluate the capacity of protein functional prediction tools in identifying and classifying protein families $[78,79]$. In this paper, an evaluation of the false discovery rate of the studied protein function predictors was performed by scanning the genomes of 4 model organisms representing 4 kingdoms (Homo sapiens from Animalia, Arabidopsis thaliana from Plantae, Saccharomyces cerevisiae from Fungi and Mycobacterium tuberculosis from Bacteria). The false discovery rates were assessed by reconstructing the prediction models of those in silico algorithms. In particular, the sequences of proteins in a certain functional family were all put into the reference database for BLAST scanning and were also used to reconstruct the machine learning models using the optimized parameters obtained in Section 3.4. In reality, the total amount of proteins not belonging to a certain family should be much larger than that of proteins in that family. Therefore, a tiny reduction in the value of $S P$ may lead to a significant discovery of false positive hits, which reminded us to use $S P$ as an effective indicator when evaluating the model's false discovery rates.

\section{Conclusions}

This study discovered substantially higher sensitivity $(S P)$ and stability $(M C C)$ of BLAST and SVM than that of PNN and KNN. However, the machine learning algorithms (PNN, KNN and SVM) were found capable of significantly reducing the false discovery rate (with PNN and KNN performed the best). In conclusion, this study comprehensively assessed the performances of popular algorithms applied to protein function prediction, which could facilitate the selection of the appropriate method in the related biomedical research.

Supplementary Materials: The Supplementary Materials are available online at www.mdpi.com/1422-0067/19/ 1/183/s1.

Acknowledgments: This work was funded by the Precision Medicine Project of the National Key Research and Development Plan of China (2016YFC0902200); the Innovation Project on Industrial Generic Key Technologies of Chongqing (cstc2015zdcy-ztzx120003); the Fundamental Research Funds for Central Universities (10611CDJXZ238826, CDJZR14468801, CDJKXB14011); and the National Natural Science Foundation of China (21505009).

Author Contributions: Feng Zhu and Lin Tao conceived of and designed the experiments. Chun Yan Yu and Xiao $\mathrm{Xu} \mathrm{Li} \mathrm{carried} \mathrm{out} \mathrm{most} \mathrm{of} \mathrm{the} \mathrm{experiments} \mathrm{in} \mathrm{this} \mathrm{paper.} \mathrm{Chun} \mathrm{Yan} \mathrm{Yu,} \mathrm{Ying} \mathrm{Hong} \mathrm{Li,} \mathrm{Hong} \mathrm{Yang,} \mathrm{Wei} \mathrm{Wei} \mathrm{Xue}$ and $\mathrm{Yu}$ Zong Chen performed the bioinformatics analysis. Feng Zhu wrote the paper. All authors read and approved the final manuscript.

Conflicts of Interest: The authors declare no conflict of interest. 


\section{References}

1. Baldi, P.; Brunak, S.; Chauvin, Y.; Andersen, C.A.; Nielsen, H. Assessing the accuracy of prediction algorithms for classification: An overview. Bioinformatics 2000, 16, 412-424. [CrossRef] [PubMed]

2. Jackson, S.P.; Bartek, J. The DNA-damage response in human biology and disease. Nature 2009, 461, 1071-1078. [CrossRef] [PubMed]

3. Weinberg, S.E.; Chandel, N.S. Targeting mitochondria metabolism for cancer therapy. Nat. Chem. Biol. 2015, 11, 9-15. [CrossRef] [PubMed]

4. Grant, M.A. Integrating computational protein function prediction into drug discovery initiatives. Drug Dev. Res. 2011, 72, 4-16. [CrossRef] [PubMed]

5. Li, B.; Tang, J.; Yang, Q.; Li, S.; Cui, X.; Li, Y.; Chen, Y.; Xue, W.; Li, X.; Zhu, F. Noreva: Normalization and evaluation of MS-based metabolomics data. Nucleic Acids Res. 2017, 45, 162-170. [CrossRef] [PubMed]

6. Li, B.; Tang, J.; Yang, Q.; Cui, X.; Li, S.; Chen, S.; Cao, Q.; Xue, W.; Chen, N.; Zhu, F. Performance evaluation and online realization of data-driven normalization methods used in $\mathrm{lc} / \mathrm{ms}$ based untargeted metabolomics analysis. Sci. Rep. 2016, 6, 38881. [CrossRef] [PubMed]

7. Xu, J.; Wang, P.; Yang, H.; Zhou, J.; Li, Y.; Li, X.; Xue, W.; Yu, C.; Tian, Y.; Zhu, F. Comparison of FDA approved kinase targets to clinical trial ones: Insights from their system profiles and drug-target interaction networks. BioMed Res. Int. 2016, 2016, 2509385. [CrossRef] [PubMed]

8. Huerta-Cepas, J.; Szklarczyk, D.; Forslund, K.; Cook, H.; Heller, D.; Walter, M.C.; Rattei, T.; Mende, D.R.; Sunagawa, S.; Kuhn, M.; et al. Eggnog 4.5: A hierarchical orthology framework with improved functional annotations for eukaryotic, prokaryotic and viral sequences. Nucleic Acids Res. 2016, 44, 286-293. [CrossRef] [PubMed]

9. Szklarczyk, D.; Jensen, L.J. Protein-protein interaction databases. Methods Mol. Biol. 2015, 1278, 39-56. [PubMed]

10. Jeanquartier, F.; Jean-Quartier, C.; Holzinger, A. Integrated web visualizations for protein-protein interaction databases. BMC Bioinform. 2015, 16, 195. [CrossRef] [PubMed]

11. Szklarczyk, D.; Santos, A.; von Mering, C.; Jensen, L.J.; Bork, P.; Kuhn, M. Stitch 5: Augmenting protein-chemical interaction networks with tissue and affinity data. Nucleic Acids Res. 2016, 44, 380-384. [CrossRef] [PubMed]

12. Franceschini, A.; Szklarczyk, D.; Frankild, S.; Kuhn, M.; Simonovic, M.; Roth, A.; Lin, J.; Minguez, P.; Bork, P.; von Mering, C.; et al. String v9.1: Protein-protein interaction networks, with increased coverage and integration. Nucleic Acids Res. 2013, 41, 808-815. [CrossRef] [PubMed]

13. Szklarczyk, D.; Franceschini, A.; Wyder, S.; Forslund, K.; Heller, D.; Huerta-Cepas, J.; Simonovic, M.; Roth, A.; Santos, A.; Tsafou, K.P.; et al. String v10: Protein-protein interaction networks, integrated over the tree of life. Nucleic Acids Res. 2015, 43, 447-452. [CrossRef] [PubMed]

14. Szklarczyk, D.; Franceschini, A.; Kuhn, M.; Simonovic, M.; Roth, A.; Minguez, P.; Doerks, T.; Stark, M.; Muller, J.; Bork, P.; et al. The string database in 2011: Functional interaction networks of proteins, globally integrated and scored. Nucleic Acids Res. 2011, 39, 561-568. [CrossRef] [PubMed]

15. Szklarczyk, D.; Morris, J.H.; Cook, H.; Kuhn, M.; Wyder, S.; Simonovic, M.; Santos, A.; Doncheva, N.T.; Roth, A.; Bork, P.; et al. The string database in 2017: Quality-controlled protein-protein association networks, made broadly accessible. Nucleic Acids Res. 2017, 45, 362-368. [CrossRef] [PubMed]

16. Finn, R.D.; Coggill, P.; Eberhardt, R.Y.; Eddy, S.R.; Mistry, J.; Mitchell, A.L.; Potter, S.C.; Punta, M.; Qureshi, M.; Sangrador-Vegas, A.; et al. The pfam protein families database: Towards a more sustainable future. Nucleic Acids Res. 2016, 44, 279-285. [CrossRef] [PubMed]

17. Li, Y.H.; Yu, C.Y.; Li, X.X.; Zhang, P.; Tang, J.; Yang, Q.; Fu, T.; Zhang, X.; Cui, X.; Tu, G.; et al. Therapeutic target database update 2018: Enriched resource for facilitating bench-to-clinic research of targeted therapeutics. Nucleic Acids Res. 2017. [CrossRef]

18. Yang, H.; Qin, C.; Li, Y.H.; Tao, L.; Zhou, J.; Yu, C.Y.; Xu, F.; Chen, Z.; Zhu, F.; Chen, Y.Z. Therapeutic target database update 2016: Enriched resource for bench to clinical drug target and targeted pathway information. Nucleic Acids Res. 2016, 44, 1069-1074. [CrossRef] [PubMed]

19. Zhu, F.; Shi, Z.; Qin, C.; Tao, L.; Liu, X.; Xu, F.; Zhang, L.; Song, Y.; Liu, X.; Zhang, J.; et al. Therapeutic target database update 2012: A resource for facilitating target-oriented drug discovery. Nucleic Acids Res. 2012, 40, 1128-1136. [CrossRef] [PubMed] 
20. Zhu, F.; Han, B.; Kumar, P.; Liu, X.; Ma, X.; Wei, X.; Huang, L.; Guo, Y.; Han, L.; Zheng, C.; et al. Update of ttd: Therapeutic target database. Nucleic Acids Res. 2010, 38, 787-791. [CrossRef] [PubMed]

21. Li, Y.H.; Wang, P.P.; Li, X.X.; Yu, C.Y.; Yang, H.; Zhou, J.; Xue, W.W.; Tan, J.; Zhu, F. The human kinome targeted by FDA approved multi-target drugs and combination products: A comparative study from the drug-target interaction network perspective. PLOS ONE 2016, 11, e0165737. [CrossRef] [PubMed]

22. Zhu, F.; Ma, X.H.; Qin, C.; Tao, L.; Liu, X.; Shi, Z.; Zhang, C.L.; Tan, C.Y.; Chen, Y.Z.; Jiang, Y.Y. Drug discovery prospect from untapped species: Indications from approved natural product drugs. PLoS ONE 2012, 7, e39782. [CrossRef] [PubMed]

23. Erdin, S.; Lisewski, A.M.; Lichtarge, O. Protein function prediction: Towards integration of similarity metrics. Curr. Opin. Struct. Biol. 2011, 21, 180-188. [CrossRef] [PubMed]

24. Sayers, E.W.; Barrett, T.; Benson, D.A.; Bolton, E.; Bryant, S.H.; Canese, K.; Chetvernin, V.; Church, D.M.; Dicuccio, M.; Federhen, S.; et al. Database resources of the national center for biotechnology information. Nucleic Acids Res. 2012, 40, 13-25. [CrossRef] [PubMed]

25. Barrell, D.; Dimmer, E.; Huntley, R.P.; Binns, D.; O'Donovan, C.; Apweiler, R. The goa database in 2009—An integrated gene ontology annotation resource. Nucleic Acids Res. 2009, 37, 396-403. [CrossRef] [PubMed]

26. The UniProt Consortium. Activities at the universal protein resource (UniProt). Nucleic Acids Res. 2014, 42, 191-198.

27. Bork, P.; Koonin, E.V. Predicting functions from protein sequences—where are the bottlenecks? Nat. Genet. 1998, 18, 313-318. [CrossRef] [PubMed]

28. Chitale, M.; Hawkins, T.; Park, C.; Kihara, D. ESG: Extended similarity group method for automated protein function prediction. Bioinformatics 2009, 25, 1739-1745. [CrossRef] [PubMed]

29. Enright, A.J.; Van Dongen, S.; Ouzounis, C.A. An efficient algorithm for large-scale detection of protein families. Nucleic Acids Res. 2002, 30, 1575-1584. [CrossRef] [PubMed]

30. Sahraeian, S.M.; Luo, K.R.; Brenner, S.E. Sifter search: A web server for accurate phylogeny-based protein function prediction. Nucleic Acids Res. 2015, 43, 141-147. [CrossRef] [PubMed]

31. Teichmann, S.A.; Murzin, A.G.; Chothia, C. Determination of protein function, evolution and interactions by structural genomics. Curr. Opin. Struct. Biol. 2001, 11, 354-363. [CrossRef]

32. Enright, A.J.; Iliopoulos, I.; Kyrpides, N.C.; Ouzounis, C.A. Protein interaction maps for complete genomes based on gene fusion events. Nature 1999, 402, 86-90. [CrossRef] [PubMed]

33. Aravind, L. Guilt by association: Contextual information in genome analysis. Genome Res. 2000, 10, $1074-1077$. [CrossRef] [PubMed]

34. Kotlyar, M.; Pastrello, C.; Pivetta, F.; Lo Sardo, A.; Cumbaa, C.; Li, H.; Naranian, T.; Niu, Y.; Ding, Z.; Vafaee, F.; et al. In silico prediction of physical protein interactions and characterization of interactome orphans. Nat. Methods 2015, 12, 79-84. [CrossRef] [PubMed]

35. Jensen, L.J.; Gupta, R.; Staerfeldt, H.H.; Brunak, S. Prediction of human protein function according to gene ontology categories. Bioinformatics 2003, 19, 635-642. [CrossRef] [PubMed]

36. Cai, C.Z.; Han, L.Y.; Ji, Z.L.; Chen, X.; Chen, Y.Z. SVM-prot: Web-based support vector machine software for functional classification of a protein from its primary sequence. Nucleic Acids Res. 2003, 31, 3692-3697. [CrossRef] [PubMed]

37. Lobley, A.E.; Nugent, T.; Orengo, C.A.; Jones, D.T. Ffpred: An integrated feature-based function prediction server for vertebrate proteomes. Nucleic Acids Res. 2008, 36, 297-302. [CrossRef] [PubMed]

38. Zhu, F.; Qin, C.; Tao, L.; Liu, X.; Shi, Z.; Ma, X.; Jia, J.; Tan, Y.; Cui, C.; Lin, J.; et al. Clustered patterns of species origins of nature-derived drugs and clues for future bioprospecting. Proc. Natl. Acad. Sci. USA 2011, 108, 12943-12948. [CrossRef] [PubMed]

39. Das, S.; Sillitoe, I.; Lee, D.; Lees, J.G.; Dawson, N.L.; Ward, J.; Orengo, C.A. Cath funfhmmer web server: Protein functional annotations using functional family assignments. Nucleic Acids Res. 2015, 43, 148-153. [CrossRef] [PubMed]

40. Wang, P.; Zhang, X.; Fu, T.; Li, S.; Li, B.; Xue, W.; Yao, X.; Chen, Y.; Zhu, F. Differentiating physicochemical properties between addictive and nonaddictive adhd drugs revealed by molecular dynamics simulation studies. ACS Chem. Neurosci. 2017, 8, 1416-1428. [CrossRef] [PubMed]

41. Xue, W.; Wang, P.; Li, B.; Li, Y.; Xu, X.; Yang, F.; Yao, X.; Chen, Y.Z.; Xu, F.; Zhu, F. Identification of the inhibitory mechanism of fda approved selective serotonin reuptake inhibitors: An insight from molecular dynamics simulation study. Phys. Chem. Chem. Phys. 2016, 18, 3260-3271. [CrossRef] [PubMed] 
42. Zheng, G.; Xue, W.; Wang, P.; Yang, F.; Li, B.; Li, X.; Li, Y.; Yao, X.; Zhu, F. Exploring the inhibitory mechanism of approved selective norepinephrine reuptake inhibitors and reboxetine enantiomers by molecular dynamics study. Sci. Rep. 2016, 6, 26883. [CrossRef] [PubMed]

43. Wang, P.; Yang, F.; Yang, H.; Xu, X.; Liu, D.; Xue, W.; Zhu, F. Identification of dual active agents targeting 5-ht1a and sert by combinatorial virtual screening methods. Biomed. Mater. Eng. 2015, 26 (Suppl. 1), 2233-2239. [CrossRef] [PubMed]

44. Li, D.; Ju, Y.; Zou, Q. Protein folds prediction with hierarchical structured SVM. Curr. Proteom. 2016, 13, 79-85. [CrossRef]

45. Wei, L.; Tang, J.; Zou, Q. Skipcpp-pred: An improved and promising sequence-based predictor for predicting cell-penetrating peptides. BMC Genom. 2017, 18 (Suppl. 7), 742. [CrossRef]

46. Wan, S.; Duan, Y.; Zou, Q. Hpslpred: An ensemble multi-label classifier for human protein subcellular location prediction with imbalanced source. Proteomics 2017, 17. [CrossRef] [PubMed]

47. Wei, L.; Xing, P.; Su, R.; Shi, G.; Ma, Z.S.; Zou, Q. Cppred-rf: A sequence-based predictor for identifying cell-penetrating peptides and their uptake efficiency. J. Proteome Res. 2017, 16, 2044-2053. [CrossRef] [PubMed]

48. Friedberg, I.; Harder, T.; Godzik, A. JAFA: A protein function annotation meta-server. Nucleic Acids Res. 2006, 34, 379-381. [CrossRef] [PubMed]

49. Wass, M.N.; Barton, G.; Sternberg, M.J. Combfunc: Predicting protein function using heterogeneous data sources. Nucleic Acids Res. 2012, 40, 466-470. [CrossRef] [PubMed]

50. Jones, P.; Binns, D.; Chang, H.Y.; Fraser, M.; Li, W.; McAnulla, C.; McWilliam, H.; Maslen, J.; Mitchell, A.; Nuka, G.; et al. Interproscan 5: Genome-scale protein function classification. Bioinformatics 2014, 30, 1236-1240. [CrossRef] [PubMed]

51. Piovesan, D.; Giollo, M.; Leonardi, E.; Ferrari, C.; Tosatto, S.C. Inga: Protein function prediction combining interaction networks, domain assignments and sequence similarity. Nucleic Acids Res. 2015, 43, 134-140. [CrossRef] [PubMed]

52. Bandyopadhyay, S.; Ray, S.; Mukhopadhyay, A.; Maulik, U. A review of in silico approaches for analysis and prediction of hiv-1-human protein-protein interactions. Brief. Bioinform. 2015, 16, 830-851. [CrossRef] [PubMed]

53. Boratyn, G.M.; Camacho, C.; Cooper, P.S.; Coulouris, G.; Fong, A.; Ma, N.; Madden, T.L.; Matten, W.T.; McGinnis, S.D.; Merezhuk, Y.; et al. Blast: A more efficient report with usability improvements. Nucleic Acids Res. 2013, 41, 29-33. [CrossRef] [PubMed]

54. Pearson, W.R. Blast and fasta similarity searching for multiple sequence alignment. Methods Mol. Biol. 2014, 1079, 75-101. [PubMed]

55. Radivojac, P.; Clark, W.T.; Oron, T.R.; Schnoes, A.M.; Wittkop, T.; Sokolov, A.; Graim, K.; Funk, C.; Verspoor, K.; Ben-Hur, A.; et al. A large-scale evaluation of computational protein function prediction. Nat. Methods 2013, 10, 221-227. [CrossRef] [PubMed]

56. Jiang, Y.; Oron, T.R.; Clark, W.T.; Bankapur, A.R.; D'Andrea, D.; Lepore, R.; Funk, C.S.; Kahanda, I.; Verspoor, K.M.; Ben-Hur, A.; et al. An expanded evaluation of protein function prediction methods shows an improvement in accuracy. Genome Biol. 2016, 17, 184. [CrossRef] [PubMed]

57. Liang, Y.; Zhang, S. Predict protein structural class by incorporating two different modes of evolutionary information into chou's general pseudo amino acid composition. J. Mol. Graph. Model. 2017, 78, 110-117. [CrossRef] [PubMed]

58. Pradhan, D.; Padhy, S.; Sahoo, B. Enzyme classification using multiclass support vector machine and feature subset selection. Comput. Biol. Chem. 2017, 70, 211-219. [CrossRef] [PubMed]

59. Meher, P.K.; Sahu, T.K.; Banchariya, A.; Rao, A.R. Dirprot: A computational approach for discriminating insecticide resistant proteins from non-resistant proteins. BMC Bioinform. 2017, 18, 190. [CrossRef] [PubMed]

60. Zhu, F.; Han, L.; Zheng, C.; Xie, B.; Tammi, M.T.; Yang, S.; Wei, Y.; Chen, Y. What are next generation innovative therapeutic targets? Clues from genetic, structural, physicochemical, and systems profiles of successful targets. J. Pharmacol. Exp. Ther. 2009, 330, 304-315. [CrossRef] [PubMed]

61. Zhu, F.; Han, L.Y.; Chen, X.; Lin, H.H.; Ong, S.; Xie, B.; Zhang, H.L.; Chen, Y.Z. Homology-free prediction of functional class of proteins and peptides by support vector machines. Curr. Protein Pept. Sci. 2008, 9, 70-95. [PubMed] 
62. Zhu, F.; Zheng, C.J.; Han, L.Y.; Xie, B.; Jia, J.; Liu, X.; Tammi, M.T.; Yang, S.Y.; Wei, Y.Q.; Chen, Y.Z. Trends in the exploration of anticancer targets and strategies in enhancing the efficacy of drug targeting. Curr. Mol. Pharmacol. 2008, 1, 213-232. [CrossRef] [PubMed]

63. Li, Y.H.; Xu, J.Y.; Tao, L.; Li, X.F.; Li, S.; Zeng, X.; Chen, S.Y.; Zhang, P.; Qin, C.; Zhang, C.; et al. SVM-prot 2016: A web-server for machine learning prediction of protein functional families from sequence irrespective of similarity. PLoS ONE 2016, 11, e0155290. [CrossRef] [PubMed]

64. Cai, C.Z.; Han, L.Y.; Ji, Z.L.; Chen, Y.Z. Enzyme family classification by support vector machines. Proteins 2004, 55, 66-76. [CrossRef] [PubMed]

65. Han, L.Y.; Cai, C.Z.; Ji, Z.L.; Cao, Z.W.; Cui, J.; Chen, Y.Z. Predicting functional family of novel enzymes irrespective of sequence similarity: A statistical learning approach. Nucleic Acids Res. 2004, 32, 6437-6444. [CrossRef] [PubMed]

66. Shen, H.B.; Yang, J.; Chou, K.C. Fuzzy KNN for predicting membrane protein types from pseudo-amino acid composition. J. Theor. Biol. 2006, 240, 9-13. [CrossRef] [PubMed]

67. Nath, N.; Mitchell, J.B. Is EC class predictable from reaction mechanism? BMC Bioinform. 2012, 13, 60. [CrossRef] [PubMed]

68. Naveed, M.; Khan, A. Gpcr-mpredictor: Multi-level prediction of g protein-coupled receptors using genetic ensemble. Amino Acids 2012, 42, 1809-1823. [CrossRef] [PubMed]

69. Hayat, M.; Khan, A. Predicting membrane protein types by fusing composite protein sequence features into pseudo amino acid composition. J. Theor. Biol. 2011, 271, 10-17. [CrossRef] [PubMed]

70. Khan, Z.U.; Hayat, M.; Khan, M.A. Discrimination of acidic and alkaline enzyme using chou's pseudo amino acid composition in conjunction with probabilistic neural network model. J. Theor. Biol. 2015, 365, 197-203. [CrossRef] [PubMed]

71. Li, H.; Yap, C.W.; Ung, C.Y.; Xue, Y.; Li, Z.R.; Han, L.Y.; Lin, H.H.; Chen, Y.Z. Machine learning approaches for predicting compounds that interact with therapeutic and ADMET related proteins. J. Pharm. Sci. 2007, 96, 2838-2860. [CrossRef] [PubMed]

72. Fujimoto, M.S.; Suvorov, A.; Jensen, N.O.; Clement, M.J.; Bybee, S.M. Detecting false positive sequence homology: A machine learning approach. BMC Bioinform. 2016, 17, 101. [CrossRef] [PubMed]

73. Pearson, W.R. Protein function prediction: Problems and pitfalls. Curr. Protoc. Bioinform. 2015, 51, 1-18.

74. Boman, H.G. Peptide antibiotics and their role in innate immunity. Annu. Rev. Immunol. 1995, 13, 61-92. [CrossRef] [PubMed]

75. Hancock, R.E.; Diamond, G. The role of cationic antimicrobial peptides in innate host defences. Trends Microbiol. 2000, 8, 402-410. [CrossRef]

76. Radek, K.; Gallo, R. Antimicrobial peptides: Natural effectors of the innate immune system. Semin. Immunopathol. 2007, 29, 27-43. [CrossRef] [PubMed]

77. Iwamuro, S.; Kobayashi, T. An efficient protocol for DNA amplification of multiple amphibian skin antimicrobial peptide cDNAs. Methods Mol. Biol. 2010, 615, 159-176. [PubMed]

78. Brown, J.B.; Akutsu, T. Identification of novel DNA repair proteins via primary sequence, secondary structure, and homology. BMC Bioinform. 2009, 10, 25. [CrossRef] [PubMed]

79. Crappe, J.; Van Criekinge, W.; Trooskens, G.; Hayakawa, E.; Luyten, W.; Baggerman, G.; Menschaert, G. Combining in silico prediction and ribosome profiling in a genome-wide search for novel putatively coding sorfs. BMC Genom. 2013, 14, 648. [CrossRef] [PubMed]

80. Virgen-Slane, R.; Rozovics, J.M.; Fitzgerald, K.D.; Ngo, T.; Chou, W.; van der Heden van Noort, G.J.; Filippov, D.V.; Gershon, P.D.; Semler, B.L. An RNA virus hijacks an incognito function of a DNA repair enzyme. Proc. Natl. Acad. Sci. USA 2012, 109, 14634-14639. [CrossRef] [PubMed]

81. Cheng, X.; Xiao, X.; Chou, K.C. pLoc-mPlant: Predict subcellular localization of multi-location plant proteins by incorporating the optimal go information into general PseAAC. Mol. Biosyst. 2017, 13, 1722-1727. [CrossRef] [PubMed]

82. Cheng, X.; Xiao, X.; Chou, K.C. pLoc-mEuk: Predict subcellular localization of multi-label eukaryotic proteins by extracting the key go information into general PseAAC. Genomics 2018, 110, 50-58. [CrossRef] [PubMed]

83. Cheng, X.; Xiao, X.; Chou, K.C. pLoc-mVirus: Predict subcellular localization of multi-location virus proteins via incorporating the optimal go information into general PseAAC. Gene 2017, 628, 315-321. [CrossRef] [PubMed] 
84. Cheng, X.; Zhao, S.G.; Lin, W.Z.; Xiao, X.; Chou, K.C. Ploc-manimal: Predict subcellular localization of animal proteins with both single and multiple sites. Bioinformatics 2017, 33, 3524-3531. [CrossRef] [PubMed]

85. Qiu, W.R.; Sun, B.Q.; Xiao, X.; Xu, Z.C.; Jia, J.H.; Chou, K.C. iKCR-PseENs: Identify lysine crotonylation sites in histone proteins with pseudo components and ensemble classifier. Genomics 2017. [CrossRef] [PubMed]

86. Chou, K.C. Impacts of bioinformatics to medicinal chemistry. Med. Chem. 2015, 11, 218-234. [CrossRef] [PubMed]

87. Chou, K.C. An unprecedented revolution in medicinal chemistry driven by the progress of biological science. Curr. Top. Med. Chem. 2017, 17, 2337-2358. [CrossRef] [PubMed]

88. Chen, W.; Feng, P.; Yang, H.; Ding, H.; Lin, H.; Chou, K.C. iRNA-AI: Identifying the adenosine to inosine editing sites in RNA sequences. Oncotarget 2017, 8, 4208-4217. [CrossRef] [PubMed]

89. Cheng, X.; Zhao, S.G.; Xiao, X.; Chou, K.C. iATC-mISF: A multi-label classifier for predicting the classes of anatomical therapeutic chemicals. Bioinformatics 2017, 33, 341-346. [CrossRef] [PubMed]

90. Feng, P.; Ding, H.; Yang, H.; Chen, W.; Lin, H.; Chou, K.C. iRNA-PseCOLL: Identifying the occurrence sites of different rna modifications by incorporating collective effects of nucleotides into PseKNC. Mol. Ther. Nucleic Acids 2017, 7, 155-163. [CrossRef] [PubMed]

91. Liu, B.; Wang, S.; Long, R.; Chou, K.C. iRSpot-EL: Identify recombination spots with an ensemble learning approach. Bioinformatics 2017, 33, 35-41. [CrossRef] [PubMed]

92. Liu, B.; Yang, F.; Chou, K.C. 21-pirna: A two-layer ensemble classifier for identifying piwi-interacting RNAS and their function. Mol. Ther. Nucleic Acids 2017, 7, 267-277. [CrossRef] [PubMed]

93. Liu, L.M.; Xu, Y.; Chou, K.C. iPGK-PseAAC: Identify lysine phosphoglycerylation sites in proteins by incorporating four different tiers of amino acid pairwise coupling information into the general PseAAC. Med. Chem. 2017, 13, 552-559. [CrossRef] [PubMed]

94. Qiu, W.R.; Jiang, S.Y.; Xu, Z.C.; Xiao, X.; Chou, K.C. iRNAm5C-PseDNC: Identifying RNA 5-methylcytosine sites by incorporating physical-chemical properties into pseudo dinucleotide composition. Oncotarget 2017, 8, 41178-41188. [CrossRef] [PubMed]

95. Qiu, W.R.; Sun, B.Q.; Xiao, X.; Xu, D.; Chou, K.C. iPhos-PseEVO: Identifying human phosphorylated proteins by incorporating evolutionary information into general PseAAC via grey system theory. Mol. Inform. 2017, 36. [CrossRef] [PubMed]

96. Su, Q.; Lu, W.; Du, D.; Chen, F.; Niu, B.; Chou, K.C. Prediction of the aquatic toxicity of aromatic compounds to tetrahymena pyriformis through support vector regression. Oncotarget 2017, 8, 49359-49369. [CrossRef] [PubMed]

97. Xu, Y.; Wang, Z.; Li, C.; Chou, K.C. iPreny-PseAAC: Identify c-terminal cysteine prenylation sites in proteins by incorporating two tiers of sequence couplings into PseAAC. Med. Chem. 2017, 13, 544-551. [CrossRef] [PubMed]

98. Chou, K.C. Some remarks on protein attribute prediction and pseudo amino acid composition. J. Theor. Biol. 2011, 273, 236-247. [CrossRef] [PubMed]

99. Chowdhury, S.Y.; Shatabda, S.; Dehzangi, A. iDNAProt-ES: Identification of DNA-binding proteins using evolutionary and structural features. Sci. Rep. 2017, 7, 14938. [CrossRef] [PubMed]

100. Filos, D.; Chouvarda, I.; Tachmatzidis, D.; Vassilikos, V.; Maglaveras, N. Beat-to-beat p-wave morphology as a predictor of paroxysmal atrial fibrillation. Comput. Methods Progr. Biomed. 2017, 151, 111-121. [CrossRef] [PubMed]

101. Rahimi, M.; Bakhtiarizadeh, M.R.; Mohammadi-Sangcheshmeh, A. Oogenesis_pred: A sequence-based method for predicting oogenesis proteins by six different modes of chou's pseudo amino acid composition. J. Theor. Biol. 2017, 414, 128-136. [CrossRef] [PubMed]

102. Sun, M.A.; Zhang, Q.; Wang, Y.; Ge, W.; Guo, D. Prediction of redox-sensitive cysteines using sequential distance and other sequence-based features. BMC Bioinform. 2016, 17, 316. [CrossRef] [PubMed]

103. Wang, Y.; Li, X.; Tao, B. Improving classification of mature microrna by solving class imbalance problem. Sci. Rep. 2016, 6, 25941. [CrossRef] [PubMed]

104. Meher, P.K.; Sahu, T.K.; Rao, A.R. Prediction of donor splice sites using random forest with a new sequence encoding approach. BioData Min. 2016, 9, 4. [CrossRef] [PubMed]

105. Bock, J.R.; Gough, D.A. Predicting protein-Protein interactions from primary structure. Bioinformatics 2001, 17, 455-460. [CrossRef] [PubMed] 
106. Karchin, R.; Karplus, K.; Haussler, D. Classifying g-protein coupled receptors with support vector machines. Bioinformatics 2002, 18, 147-159. [CrossRef] [PubMed]

107. Dobson, P.D.; Doig, A.J. Distinguishing enzyme structures from non-enzymes without alignments. J. Mol. Biol. 2003, 330, 771-783. [CrossRef]

108. Des Jardins, M.; Karp, P.D.; Krummenacker, M.; Lee, T.J.; Ouzounis, C.A. Prediction of enzyme classification from protein sequence without the use of sequence similarity. Proc. Int. Conf. Intell. Syst. Mol. Biol. 1997, 5, 92-99. [PubMed]

109. Du, R.; Mercante, D.; Fang, Z. An artificial functional family filter in homolog searching in next-generation sequencing metagenomics. PLoS ONE 2013, 8, e58669. [CrossRef] [PubMed]

110. Tian, W.; Skolnick, J. How well is enzyme function conserved as a function of pairwise sequence identity? J. Mol. Biol. 2003, 333, 863-882. [CrossRef] [PubMed]

111. Wommack, K.E.; Bhavsar, J.; Ravel, J. Metagenomics: Read length matters. Appl. Environ. Microbiol. 2008, 74, 1453-1463. [CrossRef] [PubMed]

112. Ju, Z.; He, J.J. Prediction of lysine propionylation sites using biased svm and incorporating four different sequence features into chou's pseaac. J. Mol. Graph. Model. 2017, 76, 356-363. [CrossRef] [PubMed]

113. Jia, J.; Liu, Z.; Xiao, X.; Liu, B.; Chou, K.C. iPPI-Esml: An ensemble classifier for identifying the interactions of proteins by incorporating their physicochemical properties and wavelet transforms into PseAAC. J. Theor. Biol. 2015, 377, 47-56. [CrossRef] [PubMed]

114. Jia, J.; Liu, Z.; Xiao, X.; Liu, B.; Chou, K.C. iCAR-PseCp: Identify carbonylation sites in proteins by monte carlo sampling and incorporating sequence coupled effects into general PseAAC. Oncotarget 2016, 7, 34558-34570. [CrossRef] [PubMed]

115. Liu, B.; Long, R.; Chou, K.C. iDHS-EL: Identifying DNASE I hypersensitive sites by fusing three different modes of pseudo nucleotide composition into an ensemble learning framework. Bioinformatics 2016, 32, 2411-2418. [CrossRef] [PubMed]

116. Liu, Z.; Xiao, X.; Yu, D.J.; Jia, J.; Qiu, W.R.; Chou, K.C. pRNAm-PC: Predicting n(6)-methyladenosine sites in rna sequences via physical-chemical properties. Anal. Biochem. 2016, 497, 60-67. [CrossRef] [PubMed]

117. Qiu, W.R.; Sun, B.Q.; Xiao, X.; Xu, Z.C.; Chou, K.C. iPTM-mLys: Identifying multiple lysine ptm sites and their different types. Bioinformatics 2016, 32, 3116-3123. [CrossRef] [PubMed]

118. Xu, Y.; Shao, X.J.; Wu, L.Y.; Deng, N.Y.; Chou, K.C. iSNO-AAPair: Incorporating amino acid pairwise coupling into pseaac for predicting cysteine s-nitrosylation sites in proteins. PeerJ 2013, 1, e171. [CrossRef] [PubMed]

119. Chen, W.; Feng, P.M.; Lin, H.; Chou, K.C. iRSpot-PseDNC: Identify recombination spots with pseudo dinucleotide composition. Nucleic Acids Res. 2013, 41, e68. [CrossRef] [PubMed]

120. Chou, K.C. Some remarks on predicting multi-label attributes in molecular biosystems. Mol. Biosyst. 2013, 9, 1092-1100. [CrossRef] [PubMed]

(C) 2018 by the authors. Licensee MDPI, Basel, Switzerland. This article is an open access article distributed under the terms and conditions of the Creative Commons Attribution (CC BY) license (http:/ / creativecommons.org/licenses/by/4.0/). 